\title{
Training of Skilled Personnel under the Conditions of Digital Economy
}

\author{
V. B. Dzobelova \\ North Ossetian State University after K. L. Khetagurov \\ Vladikavkaz, Russia \\ dzobelova@mail.ru
}

\begin{abstract}
The new era of digitization is accelerating, giving people not only great opportunities but also the problems associated with the transformation of the current system. The development of the digital economy in the coming years will significantly change the structure of the Russian labor market. This will cause a significant increase in their staffing with specialists of appropriate qualifications, the calculation of the needs of which should correspond to the real demands of the labor market. The article describes the main trends in the development of the system of training and advanced training under the conditions of the digital economy. The paper provides the directions of the labor market development and modernization of the Russian education system based on the study of domestic and foreign experience.
\end{abstract}

Keywords-economy; information sharing; digitization; labor market; training system; distance education; innovation technologies; platforms

\section{INTRODUCTION}

Under the conditions of globalization, the world is becoming more and more technological. Moreover, economic relations are becoming more complicated, and the virtualization of the economy is increasing. The global economy is turning into a large-scale digital world and global network market. It is the digital economy that is a powerful accelerator for innovation, growth and social well-being.

The need to ensure the digital transformation of the country's production and social processes is reflected in the national program Digital Economy of the Russian Federation and is considered as an urgent task of accelerating the economic recovery. The essence of digital transformation is the integration of modern information technologies in all aspects of business activity, which ensures the transition to the information society and Industry 4.0. [9] At the same time, the characteristic features of the development of information technologies should be taken into account: outstripping rates concerning the development of society; multiple changes in information paradigms during the generation life cycle; rapid expansion of potential applications. Nowadays, we can only give separate examples of such applications with successfully integrated information technologies. Digital Economy of the Russian Federation program sets the task of mass use of information technology in almost all areas of public activity, paying particular attention to regional digitalization.
According to experts of the World Economic Forum among the consequences of the Fourth industrial revolution will be global changes in the labor market associated with the replacement of human labor by mechanized labour. If in 2018 in 12 sectors covered by an expert report, on average $71 \%$ of the total working time was occupied by people and $29 \%$ by machinery, then by 2022 the percentage will have changed: $58 \%$ of the work will be performed by people and $42 \%$ by cars. Due to the development of this trend, it is expected elimination of 75 million traditional jobs and creation of 133 million new ones. As a result of the automation of production, workers will move into the service sector, where "human" skills are required, and strengthen the IT sector, which is rapidly becoming a key factor in the development of the economy, and which will need to be served.

\section{METHODS}

The task of personnel training for the digital economy (which is framed in an independent Federal Project) is set within the frame of the national program Digital Economy of the Russian Federation. [2]

In accordance with this program, personnel and education should be distinguished among the basic areas of the digital economy. It is noted that today the number of graduates and the content of educational programs do not meet the requirements of the digital economy. At all levels of the education system, there are not enough personnel who can work in a digital economy. In this regard, it is necessary to provide:

- creation of key conditions for personnel training for the digital economy;

- improvement of the educational system, which should provide the digital economy with competent, highly qualified personnel;

- the formation of a fundamentally new labor market, which should be based on the requirements of the digital economy;

- creation of a motivation system so that the personnel are motivated to acquire the necessary competencies and participate in the development of the digital economy of Russia.

Technological progress influences the lifestyle and nature of work of economically active citizens. Foreign researchers 
claim that soon the labor market will fundamentally change, the lifestyle and nature of work will change, so it is necessary to prepare for the periodic retraining and career guidance of personnel will be required to maintain a high level of development. [5]

According to the World Economic Forum studies, about $65 \%$ of children going to primary school today will have the jobs which do not exist yet. Education should consider these trends, adapt to the needs of the market and the characteristics of future workers, and train future workers in gaining skills which will be most demanded in the labor market afterwards.

In prospect, specialties related to science and technology, engineering and mathematics, will be in the most demand. However, today only theoretical training for new specialists is not enough. According to the studies of Harvard University scientists, the greatest demand in the labor market is for employees with social skills in team communication. They should know and fulfil the functions of management consulting, be able to build human interaction and also combine artificial intelligence with human communication based on moral principles of behavior. The machines must work for a person but not against him.

\section{ANALYSIS}

Unfortunately, the training of specialists in higher education institutions sometimes lags behind practice. Economic based on knowledge and technology depends on the ability of educational process rapid restructure and formation of new competencies and qualifications that will be more in demand on the labor market. The training system should be arranged so that there was a possibility of retraining and adaptation of acquired skills. Also, currently, technical innovations require collective production skills and high social skills among workers in these industries. Acquired skills will be constantly changing.

Economics of even the most developed countries have already changed, but the education system has not, with rare exceptions. Some skills are required, and people with other skills are entering the market. This gap is growing wider and is typical for absolutely all countries. Therefore, people are either forced to educate themselves, getting the necessary skills, or they are trained by entrepreneurs, companies, based on their tasks. At the same time, the rate of technological development is only accelerating; new professions are constantly appearing. Within the framework of the Federal project "Personnel for Digital Economy", a whole block of measures that allow training specialists faster has been laid. However, the successful implementation of this approach requires the coordinated work of a number of departments, including several ministries.

Currently, special attention should be paid to youth education, as they will have to take jobs that do not yet exist. One should start with traditional training, but it must be adapted to the specific needs of the economy and take into account the characteristics of the millennium generation. The learning process should be organized so that it could be implemented at the level of individual groups of students. This will allow using new technologies and developing and instilling a culture of communication between students. Trainees should not be passive listeners but should integrate ideas themselves and prove their significance. Teachers in this process should play the role of a master and mentor, a kind of network manager, guiding students while they pass certain stages of training and form their knowledge base, communication experience and receive technical and socia skills.

Foreign experts believe that the most effective form of training today is not the lecturer's verbal discourse, but PowerPoint or Keynote presentations, as well as case solutions and case problems. It is important to create a trial and error method so that students can evaluate the correct choice and principles of selecting the best result. Currently, leading universities in Russia are already working on such a system of education, but in general, the level of teaching in Russian education has yet to be increased in order to meet the best international standards. This requires the introduction of uniform standards of training and the adoption of state programs, the allocation of funding for the retraining of teachers. For example, Korea adopted a long-term program for the development of the education system until 2030, which implies both the introduction of new education standards and the need to introduce simulation models and innovation technologies as tools for educational process structuring, as well as using a monitoring system of the results to adjust this process.

The system of professional retraining requires close contacts with employers. Companies and organizations that attract graduates should not only provide them with jobs but also participate in the formation of the educational process, as well as develop their professional development programs for their personnel. They should develop incentive systems to retain employees based on increasing their interest in the results of their work. At present, developing retraining programs is especially important, as more and more people are becoming freelancers, i.e. self-employed, and can afford additional education. In the United States about a third of 53 million employees are now freelancers and according to studies conducted by American scientists their share will grow by 2020 .

Now technological progress is perceived ambiguously by different segments of the population. The older generation tends to see it as a threat to themselves; only $40 \%$ of young people feel fear and are afraid of losing their jobs as a result of the introduction of new technologies.

\section{RESULTS}

With the growth of technology, the service sector is growing, new jobs are being created. It requires specialists with a high level of competence on several important issues. Therefore, it is important to take into account the importance of education, which should provide the digital economy with the necessary number of labor personnel that can easily operate with information at any given time [6].

Today, the domestic educational space is rapidly growing and expanding due to the development of the digital environment: electronic textbooks are created, electronic 
library systems are formed, educational platforms appear and develop, the number of mass open online courses is measured in the thousands, and the number of their consumers - in the millions. Distance education has already firmly entered our lives.

Without the development of human capital, intensive growth of the main progressive structures is impossible: technologies and the complete informatization of society. It is obvious that its development will lead us to the creation of an adequate model of the country's economic growth and constructive cooperation between the state, business and civil society. And human capital needs special "growing" tools, the main of which are educational technologies used in the state.

The decisive role is played by the higher education system, combining educational and scientific activities, capable of providing not only targeted training and retraining of personnel, but also the scientific and production basis of digitization. The existing system of higher education in the field of information technology is heterogeneous in its capabilities in different regions and areas of activity. Under these conditions, it is advisable to formulate such tasks and strategic areas of higher education that will maximize the achievement of the results and pace of digital development of regions set by the national program "Digital Economy of the Russian Federation".

The education system will undergo serious changes at all levels. First of all, due to the widespread introduction of new educational technologies. It is they that allow removing the restrictions associated with the possibilities of age, health, as well as with the place of residence. The development of such tools has begun on the initiative of domestic universities and has been ongoing for quite a long time. In 2015, leading Russian universities established the National Open Education Platform, which hosts online courses created by the best teachers of these universities. The network interaction of educational organizations helps to improve the quality of education, i.e. students get the opportunity to study through lectures of professors from Moscow State University, Higher School of Economics, MIPT or NUST MISiS.

In 2017, the Ministry of Education and Science of Russia launched the priority project "Modern Digital Educational Environment in the Russian Federation", the purpose of which is to create conditions for systematic quality improving and expanding lifelong education opportunities for all categories of citizens through the development of the Russian digital educational space. [7]

The serious problem of the effectiveness of training organization in higher education is the process of employing graduates from low-budget institutes and colleges. Currently, a steady tendency of obtaining decent jobs by representatives of leading national and international institutions has been formed. Graduates of leading universities will easily be able to find work in their specialty after graduation. Today, it is necessary to develop systems of "social elevators" for the poorer sections of the population, to provide for the possibility of obtaining a secondary education at the expense of the company or on a budgetary basis, but under certain conditions. An important role in this system is played by distance education, which may be accessible to the general population. However, the experience of distance learning shows that students need to have basic knowledge and skills in order to complete an online education course successfully. Therefore, distance learning should be built as a second higher education or as continuing education courses. Online learning has its advantages and disadvantages over traditional forms of learning. It provides an opportunity to learn from world famous professors and to attract additional students to the training system. This system has now reached an international level, but obtaining an online education does not guarantee the employment of students after completing the course. In practice, it is difficult for them to wrest out of their residence and find a decent job. In these problems, the participation of the state and employers, and not just educational institutions, is necessary.

The main purpose of the Modern Digital Educational Environment project is the implementation of the online courses into the universities` educational programs, singling them into separate disciplines and assessing them by grades. In the next three years, the project should cover an extensive part of the areas of training of higher educational institutions both in terms of undergraduate and graduate programs. It is planned that in six years more than 10 million people a year will be trained in open online courses [4].

The portal online.edu.ru, created as the part of the project, brings together educational content located on 39 platforms; the total number of online courses available in the portal registry exceeds 1100 items in dozens of areas of training. Currently, the number of registered students has exceeded 700 thousand people who have attended online resource courses over 4.5 million times.

New educational technologies are not restricted by online courses. Today, methods that make it possible to build a personal educational trajectory for each student based on the big data analytics (the so-called "digital footprint" of the student) come to the fore.

\section{CONCLUSION}

The development of innovation technologies leads to high labor mobility within the global economy. Therefore, it is important to consider that not only knowledge exchange is necessary, but also the outflow of trainees and students is possible in cases where the level of national higher education does not meet international standards, as well as when graduates of higher educational institutions cannot find work in their specialty.

The development of innovation technologies will increase the availability of various forms of education and enhance professional skills. Probably the system of two and four years of study in higher education will change as a result of the fact that higher education will be in demand for new or related professions, as well as for workers who are in the middle of a career path.

The use of new sectorial platforms for employment in the future, as well as an increase in the number of employees without permanent employment, will lead to an increase in the 
use of digital systems and software that manage complex workflows based on tasks that are solved on demand.

Innovation technologies now allow individual users to enter global markets. In the future, this may lead to the fact that workers will independently make the transition from the category of labor suppliers to the category of owners of a certain capital. Thus, even novice lawyers will be able to attract resources independently in the market and form their law firms that will interact with other users through platform systems.

In order to meet the new needs of the labor market, higher educational institutions should provide structured and quality education, which is likely to require a revision of the student curriculum and reduction of study hours in applied disciplines. At the same time, the students should develop the basics of conceptual design and entrepreneurship, as well as social behavior skills that can prepare students for independent activity as micro-entrepreneurs in the innovation economy.

The indisputable advantage of digital technologies is the ability to ensure that each person acquires new knowledge and competencies at any stage of professional development, which is very important in a rapidly changing world.

\section{REFERENCES}

[1] Buryak V.V. Digital economy: breakthrough technologies in education. Innovacionnaya nauka [Innovative science], 2018, no. 7-8, pp. 55-59. (in Russian)

[2] Vagurina I.V. Problems of introduction of digital technologies in education. V sbornike: Transprofessionalizm kak prediktor social'noprofessional'noj mobil'nosti molodezhi Materialy Vserossijskoj ( $s$ mezhdunarodnym uchastiem) nauchno-prakticheskoj konferencii. Pod nauchnoj redakciej E.F. Zeera, V.S. Tret'yakovoj. [In the collection: Transprofessional as a predictor of socio-professional mobility of the youth Materials of all-Russian (with international participation) scientific-practical conference. Under the editorship of E.F. Zeera, V.S. Tretyakova]. 2019, pp. 340-342. (in Russian)

[3] Kotova L.R. Influence of digital technologies on education. V sbornike: Vzglyad pokoleniya XXI veka na budushchee cifrovoj ekonomiki sbornik statej prepodavatelej IX Mezhdunarodnoj nauchno-prakticheskoj konferencii "Sovremennaya ekonomika: koncepcii $i$ modeli innovacionnogo razvitiya" [In the collection: view of the XXI century generation on the future of digital economy collection of articles by teachers of the IX International scientific and practical conference "Modern economy: concepts and models of innovative development"]. 2018, pp. 183-186. (in Russian)

[4] Poletykh E.V., Chikotaeva A.A., Minyukhina Ya.O. The problem of youth employment and unemployment. Aktual'nye problemy gumanitarnyh $i$ estestvennyh nauk. [Actual problems of the humane studies and natural sciences.], no. 11-3, pp. 174-176. (in Russian)

[5] Filatova O.N., Krupa V.V., Bystrova N.V. Professional education in the strategy of digital technologies development. Problemy sovremennogo pedagogicheskogo obrazovaniya [Problems of modern pedagogical education]. 2018, no. 61-2, pp. 200-202. (in Russian)

[6] Dzobelova V.B. New Ways of Qualified Staff Training by the Example of the Republic of North Ossetia-Alania. Proceedings of 2018 17th Russian Scientific and Practical Conference on Planning and Teaching Engineering Staff for the Industrial and Economic Complex of the Region, PTES 2018, pp. 23-28.

[7] Dzobelova V.B., Olisaeva A.V. Staffing Needs in the Regional Economy under the Modern Conditions of Labor Market. Proceedings of 2018 17th Russian Scientific and Practical Conference on Planning and Teaching Engineering Staff for the Industrial and Economic Complex of the Region, PTES 2018, pp. 185-188.

[8] Dzobelova V.B., Olisaeva A.V. Analysis of innovative development of the NCFD regions in Russia. IDIMT 2018: Strategic Modeling in Management, Economy and Society - 26th Interdisciplinary Information Management Talks, 2018, pp. 473-479.

[9] Olisaeva A.V., Dzobelova V.D., Yablochnikov S.L., Cherkasova O., Davletbayeva N. Formation and development of the digital economy in modern conditions -development within the framework of industry 4.0 In the collection: IDIMT-2019. Innovation and Transformation in a Digital World TRAUNER Druck GmbH \& Co KG, Linz, 2019, pp. 8388.

[10] Rysin Y.S., Terekhov A.N., Yablochnikov S.L., Ievlev O.P., Dzobelova V.B. On the Issue of Speaker's Identification in Communication Networks and Terminal Equipment of Onboard System 2019 Systems of Signals Generating and Processing in the Field of on Board Communications, SOSG, 2019.

[11] Yablochnikov S.L., Yablochnikova I.O., Vidov S.V., Kuptsov M.I., Olisaeva A.V. The Aspects of Modeling Information Processes Realized in Complex Telecommunication Systems. In the collection: Wave Electronics and its Application in Information and Telecommunication Systems, WECONF 2018, pp. 8604360. 